\title{
Precarious Working Youth and Pension Reform in the Republic of Korea and Italy*
}

\author{
Sophia Seung-Yoon Lee ${ }^{* *}$ and Yunyoung Kim****
}

\begin{abstract}
This paper focuses on two aspects of the welfare state: the old age pension system and the labor market, where the majority of youth are working in precarious jobs. We discuss the interplay between pension funds and the increase in young atypical workers by studying the case of Italy and the Republic of Korea, closely analyzing the projected benefit level of both standard and nonstandard workers among the youth population in Korea in order to assess where young workers will find themselves after retirement age and what Korea can learn from the case of Italy.
\end{abstract}

Keywords: Pension reform, labor market, nonstandard job, precarious youth

\section{INTRODUCTION}

The attention given to the financial crisis in the Mediterranean economies has given rise to a discussion on the future of Mediterranean welfare states. While some argue that the overall high social spending and inefficiency by the government have led to financial deficit, others specifically emphasize the high proportion of social spending on old age pensions as one of the reasons (Kim, 2010). For example, in 2009, Italy, which is one of the most mature welfare states among the Mediterranean welfare states, spent 13 percent of its GDP, that is, 46.8 percent of total social expenditure, on old age pensions and pensions to surviving spouses. This is the highest level

* This work was supported by the National Research Foundation of Korea Grant funded by the Korean Government (NRF-2012S1A3A2033416). We are grateful to Emmanuele Ferragina for his help and comments regarding the Italian case in this paper.

** Assistant Professor, Department of Social Science, Ewha Womans University, Seoul, Korea. E-mail: sophia.sy.lee@ewha.ac.kr.

*** Department of Social Science, Ewha Womans University, Seoul, Korea. E-mail: yunyoung kim@gmail.com.

Manuscript received October 10, 2013; out for review October 18, 2013; review completed November 30, 2013; accepted December 2, 2013.

The Korean Journal of Policy Studies, Vol. 28, No. 3 (2013), pp. 51-75.

(C) 2013 by the GSPA, Seoul National University 
in the world; Germany spends around 9.1 percent of its GDP, Finland 10.2 percent and the United Kingdom only 6.7 percent (OECD, 2010).

The discussion about the future of the Mediterranean welfare states has also received much attention in the Republic of Korea, which is commonly seen as one of the developing welfare states among the advanced Asian economies. Here the term "developing welfare state" refers to a welfare state that has a low total social expenditure but nevertheless appears to be on a trajectory of increasing its social expenditure. In the Republic of Korea, total social spending consisted only 9.3 percent of the GDP in 2012. While there is not much consensus yet on the characteristics of the Korean welfare state and what direction it might go in, there does seem to be a fair amount of consensus on the need for further welfare state development. Korean policy makers have been closely analyzing other developed welfare states in the West in an effort to find the ideal future path, and questions as to how much the country should spend and on whom are still open to debate.

Pension reform has been at the center of the discussion in the policy-making arena in many advanced economies. Studies on pension reform have focused on the negative effect of aging on the pension fund. It has been suggested that the decreasing fertility rate and the aging population in both the East and the West may financially compromise state pension funds. At the same time, the increase in atypical workers has garnered much attention, and many studies have begun to investigate nonstandard employment using different terms, including "precarious worker," the "precariat" (Standing, 2009), "atypical employment" or "nonregular employment" (Keizer, 2008). Suggested explanations for the rise in precarious employment are globalization, deindustrialization, demographic change, and an increase in female employment. The literature explains that in postindustrial economies there is a high premium for skilled labor and educated people and that low-skilled workers are thus forced into low -value-added, low-wage jobs (Bonoli, George, \& Taylor-Gooby, 2000; Esping-Andersen, 2004; Kalleberg, 2009; Krugman, 1996; Pierson, 1994; Standing 2009).

While addressing the increase in atypical employment and undertaking old age pension reform both rank high on the political agenda in many welfare states in East Asian and in the Western European countries, the two are seldom discussed together. In the pension reform discussion in particular, the question of the future of youths and their working status is rarely discussed. Hence, this paper focuses on two aspects of the welfare state, namely the old age pension system and the labor market, where the majority of youth are working in precarious jobs. We discuss on the interplay between pension funds and the increase of young atypical workers by studying the case of the Italy and the Republic of Korea.

In investigating pension reform and its relation to the youth labor market, this 
paper adopts the method of agreement, according to which "if two or more instances of the phenomenon under investigation have only one circumstance in common, the circumstance in which alone all the instance agree, is the cause (or effect) of the given phenomenon" (Mill, 1882, p. 280). Here, Korea and Italy reveal commonalities when it comes to their labor market and pension reforms, despite numerous differences in their profiles as welfare states.

Italy has been differently classified within conservative and Mediterranean welfare state models (Esping-Andersen 1990; Ferragina \& Seeleib-Kaiser, 2011). Although it is not the objective of this article to debate the welfare regime, we can say that the Italian system shares many characteristics of conservative welfare states (social insurance dominates, generosity with respect to entitlements is based on the worker's position in the labor market, there is a medium-high level of social stratification and a medium level of decommodification) but also the peculiarities of welfare states typically found in the Mediterranean, for example, a heavy reliance on clientelism (Ferrera, 1993).

On the other hand, Korean welfare state has been commonly classified as an East Asian welfare state that shows affinities with the developmental welfare state and Confucianism welfare state. Asian welfare states have been identified as variants of "corporatism without worker participation," "subsidiarity without the Church," "solidarity without equality," and laissez-faire without libertarianism" (Jones, 1993, p. 214). Characteristics of Confucianism, which is embedded in many social norms and institutions and in much of the culture of East Asia, include respect for seniors, filial piety, paternal benevolence, a putting of the group before the individual, conflict avoidance, loyalty and dutifulness, lack of complacency, striving for learning, entrepreneurship, meritocracy, and a family orientation structured around patriarchal authority (Goodman \& Peng, 1996).

Despite these differences the form of the welfare state in the two countries, we find noticeable similarities in their labor markets and pension systems. Focusing on the precariousness of the future pension benefiters, who are the working youth now in the two countries, we investigate these similarities in order to understand how youths in both countries are experiencing or will experience precariousness.

We now take up the different welfare states of the two countries and then consider Italy, focusing in particular on its pension system and the labor market. Next, we examine Korean pension reform and the country's current pension system, including pension obligation, coverage, and replacement rate. Finally, we closely analyze the benefits both standard and nonstandard workers among the youth population in Korea can expect to receive after they retire in order to assess the probability that they will fall into poverty after retirement age, drawing conclusions about what Korea can learn from the case of Italy. 


\section{WELFARE STATES OF ITALY AND KOREA}

Italy is one of the most mature Mediterranean welfare states; it was one of the first European countries to introduce basic social policies and it has the highest level of social spending among Western welfare states. While the level of social spending has increased in Korea, the country currently spends only one third of the total on social spending of the Mediterranean welfare states, including Italy (fig. 1). However, as noted, Korea will likely increase its social expenditure in the coming years, and hence the case of Italy has a number of implications with respect to the direction that Korean welfare state development may take.

The Italian welfare state has five main characteristics (Ferrera, 1993; Ascoli, 2002). Particularism predominates over universalism; clientelism is widespread; there is a high level of dualism; cash benefits prevail over services; and a "familialistic-patriarchal" culture reigns. The prevalence of particularism over universalism reflects the conservative nature of the Italian social protection system, although there are universal features, for example, the national health care system (created in 1978), and an old age pension fund (introduced in 1979). Particularism has deep cultural and political roots. Surprisingly, the Italian left has never proposed taking the Italian welfare state in a universalistic direction (following the example of the Scandinavian countries).

In Italy, a diffused "clientelistic" culture and the use of the welfare state (as well as

Figure 1. Total Social Spending in the Mediterranean Welfare States and the Republic of Korea

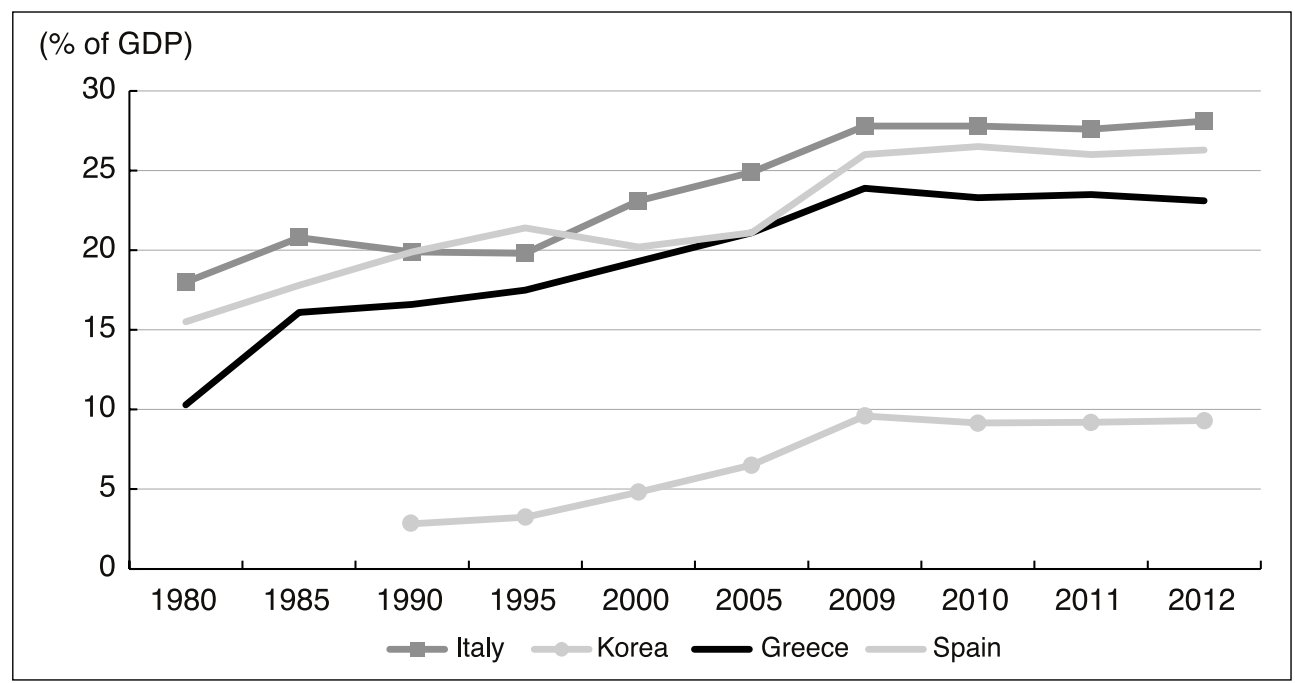

Source: OECD SOCX Database. 
public administration) to win elections is widespread. The majority of laws that have been passed in parliament were not conceived to protect citizens but rather to curry favor specific groups to gain electoral support. As shown by Ugo Ascoli (2002) between 1976 and 1980 there were 200 laws passed in the parliament to modify the pension system. This means that the Italian parliament passed an average of 40 laws every year related to pensions, which had the effect of badly fragmenting the system. Pensions become an instrument for "clientelistic politics," dramatically impacting the expenditure level. We could highlight other examples of this type, such as disability pensions that were distributed to people in poor areas or the early retirement programs (see Ascoli, 2002).

There are two main types of dualism embedded in the Italian system: a regional dualism that reveals a marked difference between the functioning of the system in the northern and the southern regions, and a generational difference, with young people highly affected by recent retrenchments in the level of generosity of unemployment benefits and the level of generosity of pension replacement rates. The superior functioning of the welfare state in the north is explained by the different modernization processes that took place in the country between the end of the 19th century and the beginning of the 20th century. Many social provisions at the time were guaranteed by "opere pie" (private religious charity). The public system successively consolidated this original structure; in the north, but while services become more efficient and widespread in the north, where opere pie was more in evidence, in the south the modern creation of the welfare state did not produce the expected outcomes. The welfare state and the public administration become in this context subject to a strong "clientelism," which provides an occasion to employ more people than necessary in areas with high unemployment rates (therefore especially in the poor regions of the south) rather than offer a real safety net of services. Sabino Cassese defines this mechanism the "meridionalization" of public administration and social services. Southern Italians have been massively employed in public administration and welfare state services in an effort to reduce unemployment rates.

The Italian welfare state has been built mostly with pensions in mind, providing a limited financial support to other welfare services, for example, unemployment welfare (0.4 percent of GDP in 2007) and family welfare (1.4 percent of GDP in 2007). The Italian welfare state is also almost entirely based on cash benefits rather than services. This is because political parties have sought to use the welfare state as an instrument to gain votes by, for example, providing cash benefits as disability pensions rather than to create a universal set of services. A welfare state based on services does not serve clientelistic purposes as readily as one based on cash assistance. The last element that characterizes the Italian welfare state is the impact of the familialistic-patriarchal culture 
that has largely excluded women from the labor market (with the result that women receive a small number of social benefits). The 1980s and 1990s brought significant change, but the position of women, especially in the southern regions, remains precarious.

The Korean welfare state was shaped against a different historical background. Lee (2011) suggests that dualism between workers in large companies and small- and medium- size companies has been intensified in the postindustrial period. That dualism has been transmogrified into one between standard and nonstandard workers. For example, Korea's national pension and insurance system initially encompassed only workers in large firms, and the disparity in welfare protection between large companies and small- and medium-size companies was large.

Ringen, Kwon, Yi, Kim, and Lee (2011) suggest that the ideology of a developmental welfare state prevailed in Korea from 1961 to 1987 and that a number of social assistance programs, social insurance, and social service programs were legislated; however, the range of these programs was still remedial and selective. From 1987 to 1998, welfare spending expanded continued to grow under Kim Dae-Jung's government. Ringen et al. (2011) have suggested that democratic consolidation and productive welfare were the prevailing ideologies in this period. Social policy has been linked with and subordinated to the supreme goal of economic development. Having rapid economic growth as its primary goal, Korea suppressed dissidence that might have challenged economic development.

One camp maintains that the Korean welfare state entered a new period after the democratization of the late 1980s that gained momentum in 1990s, while another faction argues that Korea is still a developmental welfare state (Kwon \& Holliday, 2007). However, others like Takegawa (2009) explain that it was only under Kim Dae-Jung's presidency (1998-2002) that the welfare state was established in Korea in the form of a productive welfare state. Similarly, Hort and Kuhnle (2000) suggest that East Asian countries are in many cases already following the "route to modernity" taken by their predecessors in Europe. They highlight that Korea has been gradually building a modern welfare state since the late 1980s.

Some underscore the influence of Confucianism in East Asian welfare states (Goodman \& Peng, 1996) and argue that Confucian culture is reflected in the trend toward the participation of women in the labor market. The female labor market participation rate has been around 50 percent over the past decade (49.7 percent in 2011), which is about 24 percent lower than the male labor market participation rate. The peculiarity of the Korean female labor force emerges when one examines female labor market participation rate by different education levels. While education level usually correlates with a high employment rate for women in advanced economies like Italy, in Korea, the labor market participation gap between men and women widens as 
Table 1. The Size of the Shadow Economy in Selected OECD Countries (\%)

\begin{tabular}{l|c|c|c|c|c|c}
\hline & 1999 & 2001 & 2003 & 2005 & 2007 & Average \\
\hline USA & 8.8 & 8.8 & 8.7 & 8.5 & 8.4 & 8.6 \\
\hline UK & 12.8 & 12.6 & 12.5 & 12.4 & 12.2 & 12.5 \\
\hline Germany & 16.4 & 15.9 & 16.3 & 16 & 15.3 & 16 \\
\hline Sweden & 19.6 & 19.1 & 18.7 & 18.6 & 17.9 & 18.8 \\
\hline Spain & 23 & 22.4 & 22.4 & 22.4 & 22.2 & 22.5 \\
\hline Korea, Rep. & $\mathbf{2 8 . 3}$ & $\mathbf{2 7 . 3}$ & $\mathbf{2 6 . 8}$ & $\mathbf{2 6 . 3}$ & $\mathbf{2 5 . 6}$ & $\mathbf{2 6 . 8}$ \\
\hline Italy & $\mathbf{2 7 . 8}$ & $\mathbf{2 6 . 7}$ & $\mathbf{2 7}$ & $\mathbf{2 7 . 1}$ & $\mathbf{2 6 . 8}$ & $\mathbf{2 7}$ \\
\hline
\end{tabular}

Source: Schneider, Buehn, \& Montenegro 2010.

their education level increases. A familialistic-patriarchal culture grounded in Confucianism has largely excluded women from the labor market in Korea.

Despite the differences in the characteristics and historical background of the two welfare states, there are similarities between the two countries' labor markets and pension reform initiatives. In Both Korea and Italy, a the labor force is aging fast, and there is also a large proportion of marginal workers. Schneider, Buehn, and Montenegro (2010) have calculated the size of the shadow economy in both developed and underdeveloped countries. They define the shadow economy as one that includes "all marketbased legal production of goods and services that are deliberately concealed from public authorities to avoid payment of income, value added or other taxes; to avoid payment of social security contributions; [to avoid] having to meet certain legal labour market standards, such as minimum wages, maximum working hours, safety standards, etc; and [to avoid] complying with certain administrative procedures, such as completing statistical questionnaires or administrative forms" (2010, p. 444). Both Korea and Italy have one of the largest shadow economies among the developed economies.

Labor markets in both Korea and Italy also seem to have a large proportion of nonstandard workers. The temporary employment rate is 12.8 percent (fig. 3) in Italy and 27.8 percent in Korea (fig. 5). The unemployment rate and nonstandard employment rate are higher for the youth group compared to other age groups in both countries and the rate of low-income employment is also high for this group (Nam, 2011). In the case of youth unemployment, the rate is 27.8 percent in Italy and 9.8 percent in Korea. 


\section{PENSION REFORM AND THE LABOUR MARKET IN ITALY}

Among the developed OECD countries Italy has an average level of spending (24.86 percent of the GDP [OECD, 2010]). Italy spends less than France, Sweden, Austria, Belgium, Denmark, Germany, and Finland but more than Portugal, Greece, Spain, Greece, Norway, the United Kingdom, the Netherlands, Japan, Switzerland, New Zealand, Canada, Ireland, the United States, Australia, and Korea. However, the crisis of the Italian welfare state may not have been caused by the level of expenditure but by choices the state made regarding the distribution of the spending. The lack of balance is clear if we compare the expenditure for old age pensions and surviving spouses with the expenditure for both active labor market policy (ALMP) and passive labor market policy (PLMP).

In 2007, Italy spent 14 percent of its GDP, equivalent to 57 percent of total social expenditure, on old age pensions and pensions for surviving spouses. The proportion of expenditures for cash assistance is high, while the expenditures for services are low. Social spending on unemployment protection and ALMP was less than 1 percent of the GDP (fig. 2).

The Italian pension system operated until 1996 on the basis of a defined benefit

Figure 2. Proportion of Italian GDP (\%) Expended on Old-Age, Family, and Unemployment Programs and on ALMP

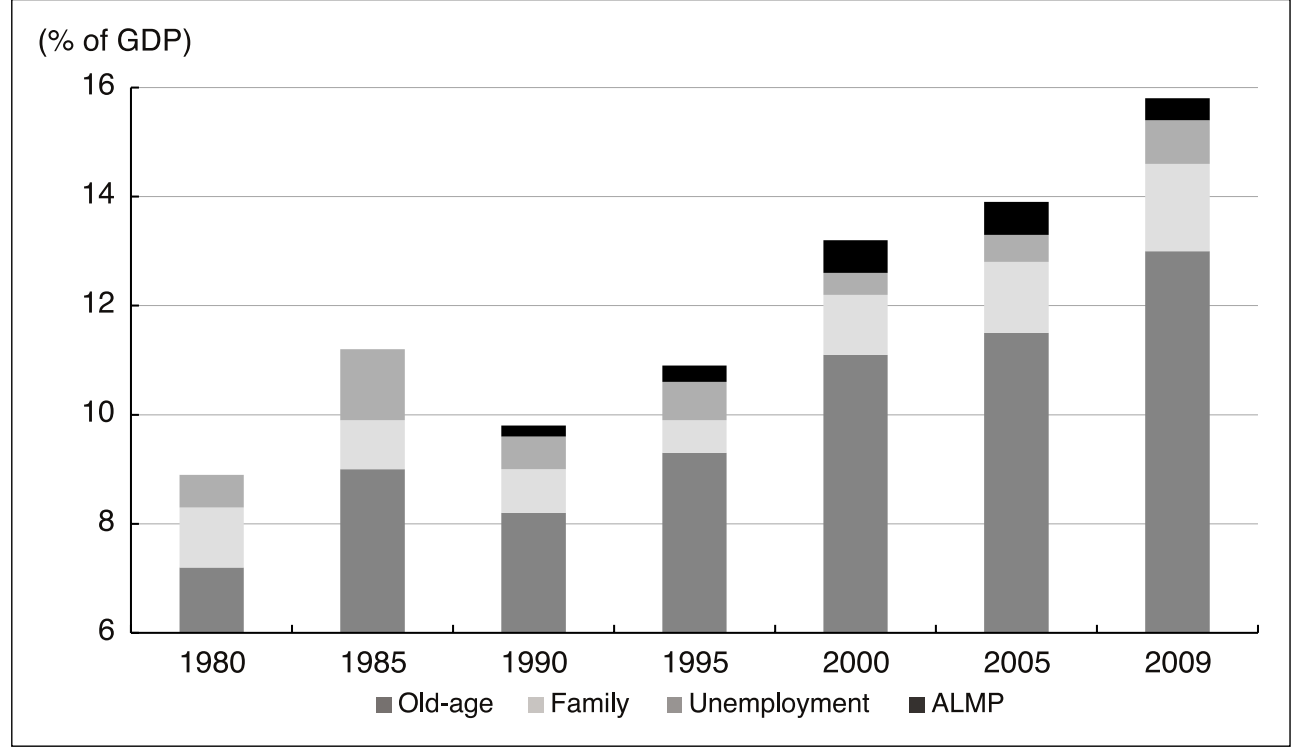

Source: OECD SOCX Database. 
(DB) mechanism. The pensions were not directly connected to the general contribution of each worker, as happens in a defined contribution (DC) system, but calculated on the basis of the last salary. The Italian system up to this time was based on the absence of reserves; all contributions were used to pay present pensions. However, the excessive generosity of the DB mechanisms (with most pensioners earning pensions that exceeded their contribution) and the clientelism brought the Italian pension system close to bankruptcy in the early 1990s.

Until the early 1990s, an individual's pension was calculated on the basis of the last salary. Therefore, those who worked for 35 years received at least 80 percent of their last stipend (this percentage went up to 95-100 percent for civil servants). On top of this, the pension was revaluated on the basis of the increase of real salaries and inflation. This system was the most generous ever created in a developed country.

The Amato reform in 1992 was the first step in the process of reform concluded in 2012. This reform increased the retirement age and instituted a revaluation of the standard pension that only took inflation into account and no longer an increase in real salaries. Furthermore, for the first time, private complementary pension schemes were introduced. The 1995 Dini reform constituted a landmark in the progressive passage from a pension system based on the DB to one based on the DC. The reform proposed a transition to a much less generous system in terms of replacement rates; thus, a worker fully enrolled in the DB system obtained a pension with a replacement rate between 80 and 100 percent of his or her last salary; a worker fully enrolled in the DC scheme obtains today a replacement rate of around 50 percent of his or her last salary. In this respect the Dini reform manifests all the elements of Italian particularism. It was necessary to avoid the explosion of the system but the reform impacted only young people. With the 1995 reform the pension system was segmented in three parts (accompanied by three different ways of calculating the replacement rates), the goal being a progressive harmonization toward the defined contribution system. The first segment includes the "privileged" that will receive their pension on the basis of a generous DC system. These people are those with more than 18 years of contribution in 1995 (basically people that started to work before 1978). The second segment includes people that started to work after 1978 and have a contributory history of less than 18 years in 1995. Their pension is now calculated using a mixed scheme (based on DB before 1995 and DC after this date). The third category includes all people who started to work after 1995. Their pension will be entirely calculated using the DC system. Payouts will consistently drop for the cohort that began work after 1995 in comparison to those of the first segment (from 80-100 percent of the last salary to 50 percent).

The problem of people who had more than 18 years of service in 1995 not having 
their pension subject to the mixed system has been partially handled by the Ferrero reform (2011-2012). Starting in 2012 all people were covered by a DC system, but only after that date. So the pension of people who had more than 18 years of contribution in 1995 will now be calculated via a mixed system: DB until 2011 and then DC after 2012. The Dini reform, along with other reforms took place after that, has been seen as monumental. In 2000, it made it possible to establish individual pension plans, and in 2004 the Maroni Reform introduced an incentive to retire later. In 2007 the Prodi reform increased the retirement age, and finally in 2011-2012 the Fornero reform (as already noted) harmonized the DC system. However, intragenerational inequity is not the sole problem of the system. There is also a very high level of inequality among people of the same generation that is strictly related to the contributory-insurance mechanisms.

One might wonder why these reforms come so late. The answer lies in the resistance of trade unions, who protected the right of people who were already in the system and disregarded young people. This disregard might be explained by the fact that members of trade unions are overwhelmingly retired or started to work before 1978 .

Italy has 18.6 million pensioners (Ferragina, 2013). 11.6 million of those retired have a pension below 1000 Euros (they represent 63 percent of the total), and Italy spends 33 percent of the pension budget on them (the aggregate average of their pension is 533 per month [Ferragina, 2013]). On the other, 2 million of those retired have a pension greater than 2000 per month. They represent 11 percent of the total, but 31 percent of the pension budget (the aggregate average of their pension is 2909s [Ferragina, 2013]). What this means is that Italy spends more or less the same amount of money on the poorest 11 million pensioners and the wealthiest 2 million. However, this difference is not justified by the contributory history, because the DB mechanism offered a very high replacement rate to people who might have insufficiently contributed to their pension. As clearly shown by Ferrera (2002), people who started to work before 1978 have contributed a bit less than half of their current pension. A large cleavage among the generations and among the pensioners of the same generation whose earning levels were different has thus been developed. The system has created the expectation of receiving a very generous pension, even though the real contribution is small. In a nutshell, Italy has created an unsustainable pension system that is currently funded by youth who are working in nonstandard jobs.

Italy spends only 0.9 percent of the GDP on ALMP and PLMP. This level is less than half of what France and Germany spend (OECD, 2010) (fig. 2). The difficulty the Italian government has faced in refashioning the labor market is intrinsically linked to the pension system and intergenerational inequality. The Italian labor market is characterized by dualism. By dualism we mean the enormous difference in the social 
Figure 3. Italian Labor Market

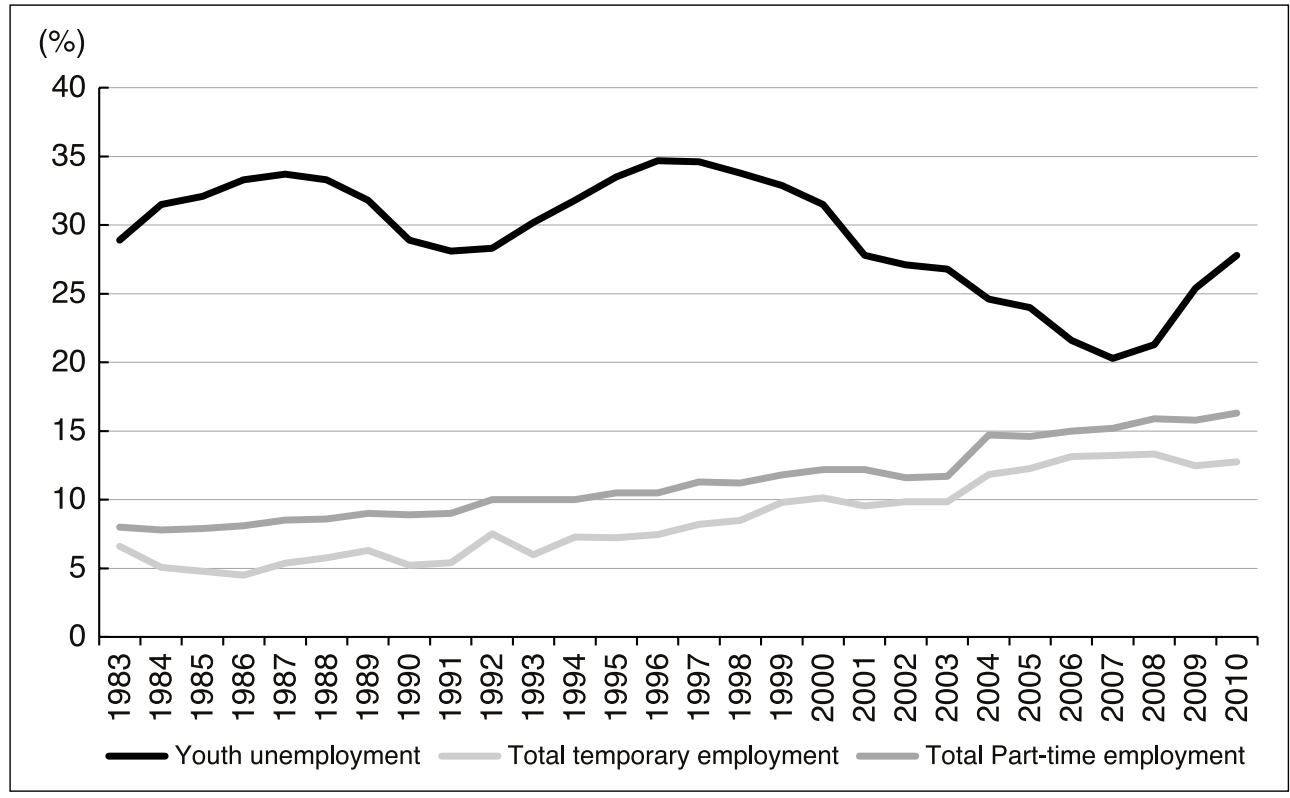

Source: ILO 2011.

benefits allocated to the insiders with a permanent contract, who will also benefit from a generous pension based on the DB system, and the outsiders with a fixed-term contract and no unemployment protection, who will receive a pension based on the DC system. The OECD employment outlook (2011) describes a situation in which the labor market is becoming more dualistic. The economic crisis has impacted mainly young people (people between the ages of 15 and 25). During the recession period, the youth unemployment rate increased by 9.7 percent, reaching 28 percent in April 2010 and there have been no signs of improvement since then. The Italian labor market is therefore more and more segmented: older workers have stable jobs, while young people have more precarious jobs (fig. 3).

The Treu reform in 1997 was intended to increase the employment rate in the southern region by providing incentives to temporary and part-time workers and by privatizing employment centers, ending the government's monopoly on employment services. Regulations for nonstandard workers were further relaxed by the Biagi reform in 2003. New job categories, such as on-call jobs and job sharing, were introduced. Labor market regulations have been reformed; permanent workers' jobs are still protected, but those of nonstandard workers are not. Despite the recent reform of the labor market (that took place in 2012), Italy does not have a universal unemployment 
benefit. This means that many people are not protected against the risk of unemployment. This situation is particularly problematic for the weakest groups (young people, women, the disabled, and migrants). Most young people employed on fixed-term contract will not receive any unemployment benefit if they will lose their job (Ferragina 2013).

\section{PENSION REFORM AND THE LABOR MARKET IN KOREA}

As in Italy, spending for old age constitutes the highest total social spending in Korea (fig. 4). The Korean national pension system was first introduced in 1973. Park (2011) explains that the national pension was established in order to secure capital to support the development of heavy and chemical industry. However, the system immediately faced difficulties due to the 1973 oil crisis and was postponed for the next 14 years. The pension was reintroduced in 1988 following the enactment of the new National Pension Act in 1986. Yang (2008) explains that the legislation was implemented to ease the tension caused by democratization and the labor movement in the late 1980s. Under the revised pension 1986 act, workers in companies with more than 10 workers were eligible to receive a pension with a replacement rate of 70 percent. The insurance rate for the contribution was 3 percent for the first five years and $6 \%$ for the following five years and 9 percent thereafter.

The Korean pension system was reformed twice after its implementation in 1988, due to projected financial difficulties. The coverage was expanded to encompass workers in companies with five or more employees in 1992 and in 1995; coverage was supposed to further be expanded by 1999 to take in rural areas and also self-employed workers, which would have made the pension system a national one that covered the entire working population. However, before a national pension system could be implemented, various issues, such as financial stability of the fund, the public's lack of trust in the government's management of the fund, and failure in to cover all working population, were raised (Kwon, 1999). In particular, the contribution level of the first pensioners was very low, while the replacement rate was high, and the aging of the population worsened the imbalance in the pension fund, leading to the first pension reform in 1998 (Kim, 2010).

The first pension reform was enacted to extend the coverage to the entire urban population, including self-employed workers in urban areas, to reduce the replacement rate of those who contributed for more than 40 years from 70 percent to 60 percent, iii), to gradually raise the age of pensioners, from 61 in 2013 to 65 by 2033, and to calculate and project the financial stability of the fund every five years. The first pension reform 
Figure 4. Proportion of Korean GDP (\%) Expended on Old-Age, Family Welfare, and Unemployment Programs and on ALMP

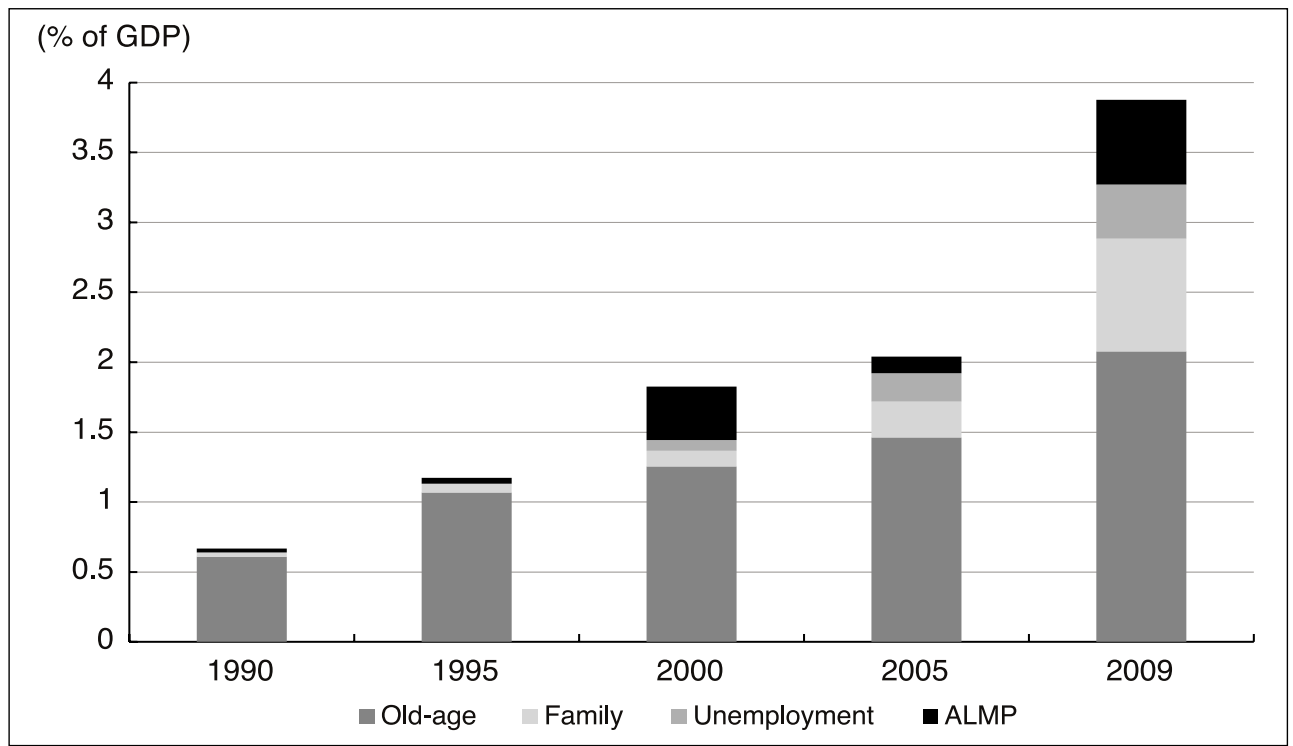

Source: OECD SOCX Database.

succeeded in adjusting the benefit level and in extending coverage to the whole population (Kim Yun-myung, 1999), but the replacement was still remained high compared to that of other countries, such as the United States (41 percent), the UK (40 percent), France (50 percent) and Canada (40 percent) (Moon, 2003).

There are different types of pensions, such as old age pensions, disability pensions, survivors' pensions, lump-sum refunds, and lump-sum death payments. The majority of the Korean pensioners are holders of the full old age pension, and generally those who contribute for between 10 to 20 years start to receive the benefit beginning at age 60 (61 starting in 2013 and 65 starting in 2033). Residents between the ages of 18 and 60 are eligible to be insured. Pension holders are categorized into workplace- based insured persons, individually insured persons, voluntarily insured persons, and voluntarily and continuously insured persons. Contribution is calculated by applying the contribution rate to the person's standard monthly income (the minimum income level is 240,000 and the maximum is $\$ 3,890,000$ ) (National Pension Service, 2012). The contribution rate is 9 percent of income; in the case of workplace-based insured persons, the employer pays 50 percent. Those who are individually insured, voluntarily insured, and voluntarily and continuously insured pay the total contribution.

The formula for the basic pension amount (pension benefit) includes a redistributive component and earnings-related element. The redistributive component is calculated 
as the average of the average monthly income (price indexed) for the last three years prior to the pension payment. The earnings-related element is the average amount of the standard monthly income of an insured person during the period he or she is insured. This earnings-related element is adjusted to match the value of income during the year prior to when the pension payments begins, and the revaluation is based on the fluctuation rate of the redistributive component. While the function of the redistributive component is to redistribute income, those who contributed little still benefit at a relatively higher level, so to correct for this, the earnings-related component is applied, which ensures that the more one contributes, the more of the benefit one receives.

The second pension reform took place in 2007 with the goal of decreasing the replacement level from 60 percent to 50 percent in 2008 to 40 percent by 2028 (table 2) and introducing a basic pension that would cover all citizens. In addition, maternal credits and military credit systems were also introduced.

The Korean pension system was introduced as a "high benefit and low contribution" system (70 percent replacement rate and 3 percent contribution rate), but since then, the government has sought to decrease the replacement rate because, as noted, the aging of the population and matured pensions created an imbalance in pension fund (Moon, 2003) (table 2). Questions on the sustainability of the pension fund have frequently been raised: the fund was projected to run out of money by 2047 unless it was reformed, and some suggested that a full pay-as-you-go system with a 39 percent contribution beginning in 2047 could defer the fund deficit until 2070 (Yoon, 2007). Parliament passed a pension reform bill on July 3, 2007; under it, those with minimum income who had contributed for 40 years and currently were receiving a pension benefit with a $60 \%$ replacement rate would receive a benefit with a 50 percent replacement rate until 2008 and a 40 percent replacement rate by 2028, the replacement rate annually decreasing by 0.5 percent. Park (2012) suggests from his analysis that the pension fund will be facing a deficit, despite the pension reforms, due to the more rapid aging of the population than had originally been projected.

Like Italy, the Korean labor market has a dual structure that was formed during industrialization and then strengthened by increased disparities between the standard and nonstandard workers (Lee, 2012). Tertiarization and slower economic growth

Table 2. Changes in the Replacement Rate in Korea

\begin{tabular}{c|c|c|c|c}
\hline & $1988-1998$ & $1999-2007$ & $2008-2027$ & after 2028 \\
\hline $\begin{array}{c}\text { Replacement } \\
\text { Rate }\end{array}$ & $70 \%$ & $60 \%$ & $\begin{array}{c}50 \% \\
\text { (reduced by 0.5\%p annually) }\end{array}$ & $40 \%$ \\
\hline
\end{tabular}

Source: National Pension Service, 2013. 
have been mediated by the dual structure between large firms and small- and mediumsize companies in Korea and Japan, creating the risk of dual labor markets, one standard, the other nonstandard. There has been a sharp increase in the number of nonstandard workers in Korea, who now make up about one third of total workers (as defined by the government). The nonstandard employment rate rose from 27 percent (2001) to 36 percent (2007) in Korea (OECD, 2008). The proportion of temporary workers in Korea is the second highest among the OECD countries (OECD, 2008), and the attention paid to nonstandard employment by both the mass media and academics in Korea mushroomed in the mid-2000s. The OECD (2010) states that part-time workers have lower hourly wages, on average, than full-time workers in almost all OECD countries. Part-time workers' hourly wages in Korea are between 50 to 60 percent of those of full-time workers (OECD, 2010).

Definition of nonstandard employment varies by scholar, institution, and country but in general describes workers who do not have a regular full-time job. In their study, Kwon, Kim, and Choi (2008) classify waged workers in Korea by the duration of the employment and by employment type. When classifying workers by duration of employment, workers are categorized as either permanent (in Korea, this refers to

Figure 5. Korean Labor Market

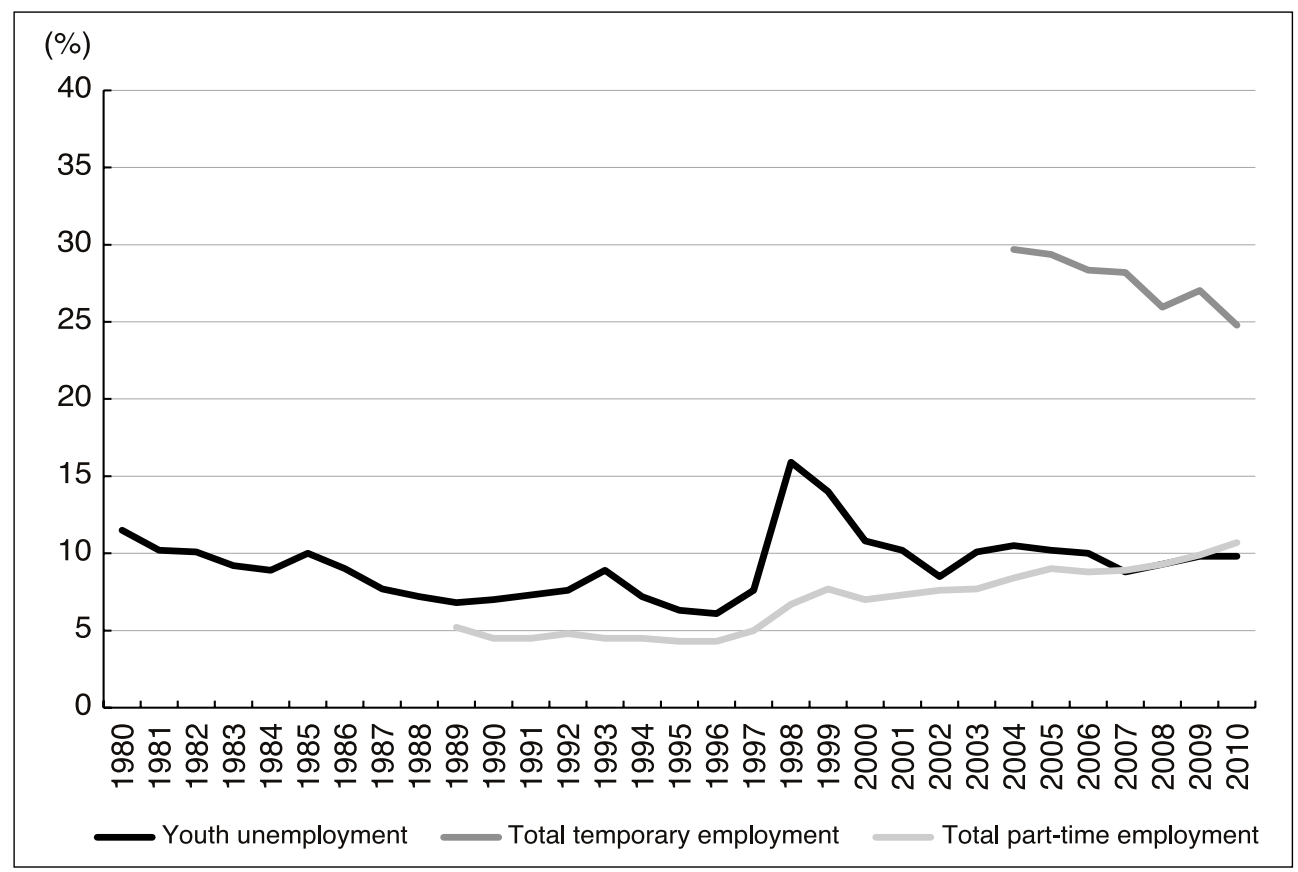

Source: ILO 2011. 
those with a permanent contract or an employment contract that is longer than one year), temporary (the employment contract is for less than one year), and daily (the employment contract is for less than one month or one day). Kwon et al. (2008) explain that when workers are categorized by employment type, they are either classified as standard or nonstandard workers, which is what the government uses for its statistics. Employment types have different components, such as employment duration, number of hours worked per week, and type of employer-employee contract type. In Korea, nonstandard workers include contingent workers who have a fixed contract, part-time workers who work less than 36 hours a week, and atypical workers such as dispatch workers, in-home workers, freelancers, and so forth who have a nontraditional employer-employee contract. Using the classification of workers by duration of employment as defined by Kwon et al. (2008), nonstandard workers, such as contingent workers, part-time workers and atypical workers, can also be permanent workers, temporary workers, or daily workers.

The youth unemployment rate in the Korean labor market is twice as high as the total unemployment rate. Hence, while the number of young people in the labor force is declining in Korea, those that remain in it are more likely to be unemployed or to be working in nonstandard jobs than the older members of the labor force (fig. 5).

\section{INTERPLAY BETWEEN PENSION REFORM AND THE PRECARIOUS LABOUR MARKET IN KOREA}

In this section, we conduct an analysis of the replacement rate of the pension workers in Korea receive when they reach retirement age. As in Italy, nonstandard workers are not securely insured by a pension system in Korea. The most precarious workers are nonstandard workers (contingent workers, part-time workers, atypical workers) who have employment contracts of less than one year; as note, the majority of the youth population in Korea are nonstandard workers.

Nonstandard workers are eligible for the national pension system as workplacebased insured persons. In addition, coverage of Korean national pension was expanded in 2006 to covers workers in all places of employment (including self-employed workers as individually insured persons and places of employment with one or more workers). However, in 2007, only 13.9 percent of nonstandard workers were insured by the national pension. Comparing the rate of permanent and standard workers, which is 98.7 percent, we can infer that nonstandard workers are excluded from the national pension system due to their precarious working conditions. Kwon et al. (2008) suggest that the short employment period, loss of job, and a low level of income hinder workers 
Table 3. Insured Rate, Average Monthly Income, and Average Duration of Employment by Employment Status in Korea

\begin{tabular}{c|l|c|c}
\hline Year & \multicolumn{1}{|c|}{ Category } & Standard & Nonstandard \\
\hline \multirow{3}{*}{2012} & Rate of Insured Pension (\%) & 79.6 & 40.5 \\
& Average Monthly Income (per 1000) & 245.4 & 143.2 \\
& Average Working Period (Month) & 81 & 29 \\
\hline
\end{tabular}

Source: Statistics Korea, 2012.

from making a contribution leading that would at least provide them with a small pension.

Not only is the coverage rate difference between standard workers and nonstandard worker as high as 40 percent, but the average monthly income level of nonstandard workers is about million lower than the standard workers. The average duration of employment is also about 50 months shorter in the case of nonstandard workers. The low level of income, short total duration of employment, and the low rate at which precarious workers are insured affects both the total amount of contributions made to their pensions and the security of these precarious workers in old age.

Compared to other OECD countries, Korea has one of the highest rates of selfemployment, although the number of self-employed is declining. In Korea, the proportion of waged and salaried workers increased from around 47 percent in 1980 to 68.15 percent in 2007, which is more than a 20 percent increase. However, the proportion of self-employed workers decreased only about 10 percent in 2011 , to 28 percent (the proportion of self-employed workers decreased by 12 percent in Germany, 7 percent in United States, 12 percent in Japan, and 25 percent in Italy in 2011). Both Korea and Italy stand out as having a high rate of self-employed workers. Self-employed workers in Korea refer to workers who are employers but who do not necessarily have any employees (or those who have family members working for them but do not pay them a wage) (Kim, 2012a). Self-employed workers in Korea frequently enter and exit the labor market, which is what gives rise to their precarious working status. In addition, irregular income levels of self-employed workers of small businesses face difficulties in getting insured. Self-employed workers in Korea have both less income security and employment security compared to waged workers, and so their insured rate is relatively low (Kim, 2012a). ${ }^{1}$

1. In principle, self-employed workers can be included in the individually insured person category in the Korean national pension system, but due to difficulties in collecting their contribution, they are separately classified as workplace-based snsured person. 
Table 4. Pension Coverage Rate by Employment Types in Korea (2011)

\begin{tabular}{l|c|c}
\multicolumn{1}{c|}{ Category } & Pension Insurance rate (\%) & Number of Insured \\
\hline Self-Employed & 57.26 & 3,149 \\
\hline Waged Workers, Total & 64.23 & 18,166 \\
\hline Full-Time Workers & 93.97 & 14,540 \\
\hline $\begin{array}{l}\text { Temporary Workers } \\
\text { (Less Than One Year) }\end{array}$ & 34.89 & 3,093 \\
\hline $\begin{array}{l}\text { Short-Term Contract Workers } \\
\text { (Less Than One Month) }\end{array}$ & 13.51 & 533 \\
\hline
\end{tabular}

Source: Statistics Korea 2011.

The increase of nonstandard workers, high proportion of self-employed workers, and the large number of unemployed youth have a number of implications for the pension fund. Kim (2012a) explains that contribution and pension benefit are highly related to individual's income level in Korea the two most important factors determining an individual's pension is his or her average income and duration of employment. In her studies on the relationship between self-employed workers and pensions, Kim (2012a) suggests that self-employed workers are more likely to face income insecurity after retirement, as their income level and employment status is more precarious than that of regular waged workers, which may affect their contribution period.

Compared with the pension entitlement rates of the total number of waged workers, the rate of self-employed workers is lower. Insurance rates of temporary workers (about 35 percent) and short-time workers (about 13.5\%) are substantially lower than those of full-time waged workers, which are about 35 percent. Frequent movement in and out the workplace and their relatively low level of income means non-standard workers and self-employed workers will likely find it difficult to contribute to the pension system.

Precarious workers in both Korea and Italy are not likely to be able to increase the amount of the pension benefit they will receive in the short term for two reasons. The first has to do with the decreasing replacement rate and the second relates to the way the pension benefit is calculated. In the case of Italy, the gap between generations with a defined benefit versus a defined contribution has widened in the wake of a series of pension reforms. Likewise, in Korea, the replacement rate for those who are covered before 1998 is 70 percent, whereas the rate for those who joined the program after 2028 is 40 percent (table 2). Furthermore, the Korean pension system is built on the assumption of workers being employed in long-term jobs. That is, the 40 percent replacement rate was established using those who contribute for 40 years as the frame 
of reference. However, it is not likely that many workers in Korea will be able to regularly contribute to the pension for 40 years due to the high proportion of those working in nonstandard jobs. As table 5 shows, both the average duration of employment and average income for nonstandard workers are substantially lower than that of the standard workers.

The current youth in Korea faces an even more precarious future than the youth in Italy. The unemployment rate for those between age 15 and 29 increased during the years 2000 to 2009, while the employment rate decreased (Nam, 2011). Furthermore, while the total temporary employment rate is decreasing, the rate among young people is increasing, indicating that the working environment for them is becoming more precarious. Young workers in Korea are relatively more exposed to low income after retirement compared to the present owing to a pension system that is much less favorable to youth than to the older generation.

For this study, we first analyzed the benefit level of precarious workers to assess their probability of falling into poverty after retirement age. We compared the average income level and duration of employment of standard and nonstandard workers and found that for nonstandard workers they are only about 60 percent of those of standard workers, indicating a lower level of pension benefits for nonstandard as compared to standard workers (table 5).

Next, we conducted a more detailed analysis of pension benefit levels by age group and by employment status. The reason for calculating the benefit level for standard workers and nonstandard worker separately is that the difference between them with respect to average income level and average duration of employment is large. The pension calculator provided by the Korean National Pension Fund (http://csa.nps.or.kr/ finance/pensionCal.do) requires information as to the initial year of contribution, years of enrollment, and monthly income level. We calculated the replacement rate for those aged 25, 35, 45 and 55 in 2013. The initial year of contribution is 2013, 2003, 1993 and 1990, respectively. The income level and contribution period are calculated differently for standard workers and nonstandard workers, according to the data provided by Sung Eun Mi (2007), who conducted an analysis using data from 1999 and 2005 the

Table 5. Average Income and Working Period of Standard and Nonstandard Employment

\begin{tabular}{l|c|c}
\hline & $\begin{array}{c}\text { Average Income } \\
\text { (per } \# 10,000)\end{array}$ & $\begin{array}{c}\text { Average Duration of Employment Period } \\
\text { (by Months) }\end{array}$ \\
\hline Standard & 245.4 & 267 \\
\hline Nonstandard & 143.2 & 153 \\
\hline
\end{tabular}

Source: Statistics Korea, 2012, and Seong, 2007. 
Korean Labour and Income Panel Study (KLIPS). In making her calculations, she assumed that employment patterns of individuals over a 7-year period was typical and would be repeated until retirement age.

According to KLIPS, on average, standard workers contribute to the pension for about 4.1 years out of 7 years, while nonstandard workers contribute 1.21. Assuming that workers work from the age of 25 to 60 , meaning 35 years, we calculated that standard workers contribute for 267 months $(4.10 / 7)^{*}\left(35^{*} 12\right)=267$ months $)$ and that nonstandard workers contribute 153 months $(1.21 / 7)^{*}\left(35^{*} 12\right)=153$ months $)$. Here we disregard yearly price fluctuations in order to compare the value of the pension benefit among different age groups at a given time point.

The results presented in table 6 indicate that the projected pension benefit of nonstandard workers is 30 percent to 40 percent less than that of standard workers. Moreover, we can infer that the projected pension benefit of 25 year olds is 40 percent to 50 percent less than that of those who are currently in their 50s. The situation is the worst for those in the age 25 group who have nonstandard jobs. The projected pension benefit for the 55 year olds is $\$ 87,350$, while it is $\$ 518,850$ for the 25 year olds in the case of standard workers, while in the case of nonstandard workers the benefit level is $\$ 527,250$ for the 55 year olds and $\$ 237,450$ for the 25 year olds. Young nonstandard workers will receive only fourth quarter of the benefit of 55-year-old standard workers and about half of the benefit of the 55-year-old nonstandard .

Results from our analysis suggest that the youth group is projected to receive a

Table 6. Projected Pension Benefit of Standard and Nonstandard Workers by Age Group and

\begin{tabular}{|c|c|c|c|c|c|c|c|}
\hline & Age & $\begin{array}{l}\text { Contribution } \\
(\%) \text { in } \\
\text { First Year }\end{array}$ & $\begin{array}{l}\text { Amount } \\
\text { Received } \\
(\%) \text { in } \\
\text { First Year }\end{array}$ & $\begin{array}{l}\text { Contribution } \\
\text { Period } \\
\text { (Months) }\end{array}$ & $\begin{array}{c}\text { Average } \\
\text { Income } \\
(\# 10000)\end{array}$ & $\begin{array}{c}\text { Pension } \\
\text { Age }\end{array}$ & $\begin{array}{c}\text { Projected } \\
\text { Pension } \\
\text { Benefits } \\
\text { (\#) }\end{array}$ \\
\hline \multirow{4}{*}{ Standard } & 55 & 90.01 & 12.03 & \multirow{4}{*}{267} & \multirow{4}{*}{245} & 62 & 987,350 \\
\hline & 45 & 93.01 & 15.03 & & & \multirow{3}{*}{65} & 851,610 \\
\hline & 35 & 03.01 & 25.03 & & & & 618,450 \\
\hline & 25 & 13.01 & 35.03 & & & & 518,850 \\
\hline \multirow{4}{*}{ Nonstandard } & 55 & 90.01 & 02.09 & \multirow{4}{*}{153} & \multirow{4}{*}{143} & 62 & 527,250 \\
\hline & 45 & 93.01 & 05.09 & & & \multirow{3}{*}{65} & 449,370 \\
\hline & 35 & 03.01 & 15.09 & & & & 297,940 \\
\hline & 25 & 13.01 & 25.09 & & & & 237,450 \\
\hline
\end{tabular}

Source: National Pension System, 2013. 
substantially lower pension benefit, regardless of their working status, and that the situation is worse when they work in nonstandard jobs. This is due to the decreasing replacement rate $(-0.5$ percent $\mathrm{p})$ and if we take into account the increasing nonstandard employment rate among the youth group, the pension benefits of the young workers are likely to further decrease. The pension benefit will be substantially insufficient to cover a decent income of the youth when they retire. That is, the future of the youth group in Korea seems especially more precarious compared to other age group, since they face double the risk of working in non-standard jobs and also receive pensions with a lower replacement rate (table 6).

\section{CONCLUSION}

This paper has focused on two aspects of the welfare state: the old age pension system and the labor market, where the majority of the youth are working in precarious jobs. We have discussed on the interplay between pension and the increase of young nonstandard workers by closely examining the pension systems in Italy and Korea, using the case of the Italian welfare state to consider implications for Korea.

The Italian welfare state has been constructed mostly on the basis of pensions, providing limited financial support for other welfare services, and overwhelmingly provides cash assistance in lieu of services. The crisis of the Italian welfare state may not have been caused by the level of expenditure but by choices regarding the distribution of the spending. While a large share of welfare spending is allocated for old age pensions, spending on the labor market, the family, and youth group is limited. Italy has created an unsustainable pension system: young people who are working in a precarious labor market are currently paying for the pension but increasing spending on young people is difficult due to structure of welfare spending.

As in Italy, spending on old age pensions constitutes the highest total social spending in Korea. However, with a comparatively low level of total social spending, Korea is mostly likely on the trajectory of increasing its welfare expenditure. As we noted at the beginning, the ideal future path and questions as to how much the country is to spend and on whom is still open to debate.

The study suggests that the pension benefit that Koreans who are young now will receive will be insufficient to provide even the minimum income for them when they retire. In other words, the future of the current youth cohort in Korea seems more precarious than that of other age groups: this cohort faces the double risk of working in nonstandard jobs and also of receiving a pension with a lower replacement rate. Moreover, in the case of Korea, the pension benefit level is structured to be twice as 
high as the contribution level, meaning that the younger generation is paying for the future generation's pension benefit (Kim, 2004). The 2030 labor force is likely to be composed largely of teenagers or adolescents in their 20s, and they are likely to be employed in nonstandard jobs or else unemployed. Lower pension coverage of this young generation indicates their precarious status in the labor market and also their precarious future.

This paper has demonstrated how the precarious status of youth people in the labor market is closely associated with the their future pension benefit owing to the current pension structure. This study suggests that the interplay between the precarious labor market and the pension structure may result in income insecurity for current young people employed in nonstandard jobs when they retire. Based on the analysis from this paper, we can offer some policy suggestions, one of which is that the government should intercede to address the precarious youth labor market in Korea. Korean youth are more highly concentrated in nonstandard jobs compared to other age groups, and the current pension structure creates blind spots by failing to cover these nonstandard employments.

The government has been focusing on solving the issue of limited pension coverage by expanding the compulsory enrollment in the pension program to any place of employment with more than one worker. Also the Act for Protecting Temporary Workers was introduced in 2007 to encourage employers to rehire their nonstandard workers as regular workers. However, the pension coverage of nonstandard workers still remains only half of that of the standard workers. Reason for this low level of coverage is that both employers and employees have tended to opt out of the national pension program to avoid the burden of contribution (Kang, 2008).

To address this problem, the government implemented the Duru-nuri social insurance policy, which was intended to subsidize pension contributions for employers with fewer than 10 employees who receive less than 1300,000 a month. This policy has been only in effect nationwide since July 2012. Hence it is not possible yet to evaluate the effect of the policy. However, we predict that the legislation will serve to expand coverage of young people working in nonstandard jobs, since one of the main reasons the coverage has been so low is that employers who own small companies are unable to contribute on behalf of their employees.

The low level of average income of nonstandard workers - the average monthly income of nonstandard workers is 1120,000 lower than that of standard workers (Statistics Korea, 2013) - is another critical reason for the low level of projected pension benefits for them. The Park Geun-hye government has recently developed and highlighted the policy of the time-selective job. This policy's purpose is to subsidize social insurance contribution and guarantee workers 130 percent of the statutory minimum 
wage. We can look forward to a decrease in the female and elderly unemployment rate and a bettering of their working conditions, as this policy mainly targets women whose careers have been interrupted due to child rearing and baby boomers who are now retiring. However, this legislation may have only a limited effect on the problem of the income insecurity the youth in the labor market face now and will continue to face when they retire.

Therefore, a more fundamental policy that focuses on the precarious youth labor market should be considered. The case of Italy suggests that the path dependence of the welfare spending structure can produce not only a welfare state crisis but also a precarious labor market made up of a large cohort of large youth people who face income insecurity both before and after retirement age.

The working status of large numbers of Korean youth is precarious, and the lack of attention given to this group and the concomitant focus on pension spending for current benefiters may result in the Korean welfare facing similar welfare state challenges as in Italy. Korea's social spending is about 10 percent of the GDP, and it is projected to grow. Given this critical situation, this paper suggests that Korea should increase its labor market welfare spending, especially focusing on the youth population as its faces the burden of income insecurity both in present and in the future.

\section{REFERENCES}

Ascoli, U. 2002. Le caratteristiche fondamentali del welfare state italiano: La collana degli Archivi di stato. http://www.sissco.it/index.php?id=228.

Bonoli, G., George, V., \& Taylor-Gooby, P. 2000. European welfare states: Towards a theory of retrenchment. Cambridge: Polity Press.

Chung, M. G. 2006. The Korean developmental welfare regime. Journal of Social Policy and Labor Studies, 16: 149-171.

Esping-Andersen, G. 1990. The three worlds of welfare capitalism. Princeton, N.J.: Princeton University Press.

Esping-Andersen. G. 2004. Untying the Gordian knot of social inheritance. Research in Social Stratification and Mobility, 21: 115-138.

Ferrera, M. 1993. Modelli di solidarieta. Bologne: Mulino.

Ferrera, M. 2002. Politiche contro la povertà: Il welfare dei paradossi. La Voce, July 23. http://www.lavoce.info/articoli/pagina42.html.

Ferragina, E. 2013. Il paese delle disuguaglianze inaccettabli. Milan: Rizzoli.

Ferragina, E., \& Seeleib-Kaiser, M. 2011. Welfare regime debate: Past, present, futures. Policy \& Politics, 39 (4): 583-611. 
Goodman, R., \& Peng, I. 1996. The East Asian welfare states: Peripatetic learning, adaptive change, and nation-building. In G. Esping-Andersen (ed.), Welfare states in transition: National adaptations in global economies (pp.). London: Sage.

Holliday, I. 2000. Productivist welfare capitalism. Social policy in East Asia, 48: 706-723.

International Labour Organization [ILO]. 2011. Key indicators of the labour market [KILM]. 7th ed. Geneva: International Labour Organization.

Kalleberg, A. L. 2009. Precarious work, insecure workers: Employment relations in transition. American Sociological Review, 74 (1): 1-22.

Kang, S. H., Kim, T. W., \& Kim, M. K. 2008. Estimate of national pension nonbenefiters and policy recommendations for addressing the issue. Seoul: National Pension Research Institute.

Keizer, A. B. 2008. Non-regular employment in Japan: Continued and renewed dualities. Work, Employment and Society, 22 (3): 407-425.

Kim, K. A. 2012a. The self-employed and national pension system in South Korea. Korean Social Security Association, 1: 165-190.

Kim, K. A. 2012b. Social protection by working status and related issues. Pension Forum, 46: 61-66.

Kim, P. H. 2010. The East Asian welfare state debate and surrogate social policy: An exploratory study on Japan and South Korea. Socio-Economic Review, 8 (3): 411-435.

Kim, Y. M. 1999. The unstable universal national pension and its effect. Monthly Welfare Trend, 15: 10-13.

Kim, Y. M. 2004. Why are there so many defaulters on the national pension? Monthly Welfare Trend, 70: 20-22.

Kim, Y. M. 2010. Reexamination of the exclusion of nonstandard employment from social insurance coverage in Korea. Social Welfare Policy, 37(4): 155-179.

Krugman, P. R. 1991. First, do no harm. Foreign Affairs, 75 (4): 164-170.

Kwon, H. J., Kim, S. H., \& Choi, E. A. 2008. Policies for nonstandard workers' national pension coverage. National Pension Research Institute Working Papers, 12.

Kwon, M. I. 1999. Issues in the development of the national pension. Korean Journal of Social Welfare Studies, 14 (1): 1-42.

Lee, S. H. 2012. Overeducation in youth labor markets: Focusing on spatial effects. Space and Society, 40: 38-77.

Lee, S. S. 2011. The shift of labor market risks in deindustrializing Taiwan, Japan, and Korea. Perspectives on Global Development \& Technology, 10 (2): 241-269.

Moon, H. P. 2003. Background and challenges of national pension reform. International 
Trade Business Institute Review, 9 (2): 103-121.

Nam, J. R., Lee, C. I., Chun, Y. J., \& Woo, S. J. 2011. Policy implications of Entering and Remaining in the youth labour market. Seoul: Korea Labor Institute.

National Pension System. 2012. http://www.nps.or.kr.

Navarro, V. 2011. Crisis and class struggle in the Eurozone. Counterpunch, August 19-21. http://www.counterpunch.org/2011/08/19/crisis-and-class-struggle-in-the -eurozone.

OECD. 2008. OECD economic surveys: Japan 2008. Paris: OECD.

OECD. 2010. OECD employment outlook 2010. Paris: OECD.

Oh, J. S. 1987. Policy making process and the legislative history of the national pension system in Korea. Korean Social Security Studies, 3(1): 143-164.

Park, B. H. 2011. Social welfare policy. Paju: Hakhyunsa.

Park, J. G. 2012. 2012-2060 Projection and Analysis of Long-term Budget. Seoul: National Assembly Budget Office.

Pierson, P. 1994. Dismantling the welfare state? Reagan, Thatcher, and the politics of retrenchment. Cambridge: Cambridge University Press.

Ringen, S., Kwon, H., Yi, I., Kim, T., \& Lee, J. 2011. The Korean state and social policy: How South Korea lifted itself from poverty and dictatorship to affluence and democracy. New York: Oxford University Press.

Schneider. F., Buehn, A., \& Montenegro. C. 2010. New estimates for the shadow economies all over the world. International Economic Journal, 24 (4): 443-461.

Seoung, E. M. 2007. A study of the pension and unemployment insurance benefits rate of nonstandard workers. Social Welfare Policy, 29 (4): 95-120.

Standing, G. 2009. Work after globalization. Cheltenham, UK: Edward Elgar.

Statistics Korea. 2011. Economically Active Population Survey 2012. Seoul: Statistics Korea.

Statistics Korea. 2012. Economically Active Population Survey 2012. Seoul: Statistics Korea.

Statistics Korea. 2013. Economically Active Population Survey 2013. Seoul: Statistics Korea.

Yang, J. J. 2007. The social investment state is the welfare state model for Korea: A reply to critics of the social investment state. Economy and Society, (75): 319-335.

Yang, J. J. 2008. Korean welfare policy 60 years later: Formation of the Developmental welfare regime and the need for transformation. Korean Public Administration Review, 42 (2): 327-349.

Yoon, S. M. 2007. A critical review of the national pension reform debates. Health and Welfare Policy Forum, 129: 67-83. 